\title{
Long-Term Neurological Threats of COVID-19: A Call to Update the Thinking About the Outcomes of the Coronavirus Pandemic
}

\author{
Antonio Pereira* \\ Electrical and Biomedical Engineer Department, Institute of Technology, Federal University of Pará (UFPA), Belém, Brazil
}

Keywords: COVID-19, synucleinopathy, neurotropism, coronavirus (CoV), SARS-CoV

Since 11 March 2020, The World Health Organization has characterized coronavirus disease 2019 (COVID-19), caused by SARS-CoV-2 (1) as a pandemic. The outbreak started in the city of Wuhan in China and quickly spread worldwide. Coronaviruses have previously caused two large-scale pandemics in the past two decades, SARS (2) and Middle East respiratory syndrome (MERS) (3). SARS-CoV-2 is closely related to other CoV found in zoonotic reservoirs, such as bats, camels, and pangolins (4). Since SARS-CoV-2 is considerably more infectious than both SARS-CoV and MERS-CoV, many countries have determined a strict policy of "shelter-in-place" to contain the virus spread through social contagion. However, many questions remain regarding the clinical

OPEN ACCESS

Edited by:

Robert Weissert,

University of Regensburg, Germany

Reviewed by:

Michael Levy,

Harvard Medical School,

United States

*Correspondence:

Antonio Pereira apereira@ufpa.br

Specialty section:

This article was submitted to

Multiple Sclerosis and

Neuroimmunology,

a section of the journal

Frontiers in Neurology

Received: 25 March 2020

Accepted: 31 March 2020

Published: 17 April 2020

Citation:

Pereira A (2020) Long-Term Neurological Threats of COVID-19: A Call to Update the Thinking About the Outcomes of the Coronavirus Pandemic. Front. Neurol. 11:308. doi: 10.3389/fneur.2020.00308 outcomes of human infection by SARS-CoV-2, including the possibility of the development of neurological disorders (5).

Some viruses possess a tropism for neural tissue and are thus classified as neurotropic (e.g., herpes simplex virus type 1 , rabies virus). Those viruses enter the brain through various routes, including retrograde axonal transport along axons, hematogenous spread via the blood-brain barrier (BBB), blood-cerebrospinal fluid barrier, meningeal-cerebrospinal fluid barrier, via direct infection of endothelial cells or through spreading of infected leukocytes to the brain across the $\mathrm{BBB}$ (6). Once in the brain, these viruses disrupt the complex organization of neural circuits either directly by neuronal damage or indirectly through host immune response pathways, causing immediate, or delayed neuropathology and neurological manifestations (6) (see below). In the short-term, neurotropic viral infections can cause inflammation of the brain parenchyma and lead to encephalitis or brain-targeted auto-immune responses in susceptible individuals (7). Possible long-term effects on hosts can include alterations on emotional and cognitive behavior, as shown in experimental animals through persistent alterations in the expression of genes involved in the regulation of synaptic activities in key brain areas (8). The axonal transport of neurotropic viruses can also turn intrinsically disordered proteins, such as $\alpha$-synuclein ( $\alpha$-syn), into promiscuous binders that can form toxic aggregates and travel along neuronal pathways and cause cell death in areas of the brain (9).

While the most common symptoms of COVID-19 at the onset of illness include fever, fatigue, dry cough, myalgia, and dyspnea, other less common symptoms are headache, abdominal pain, diarrhea, nausea, and vomiting (10). Furthermore, it's been recently reported that most patients also complain of impairment of both olfactory and gustatory perception (11) and those are being considered early markers of COVID-19 infection. Though there is longstanding evidence that human coronaviruses, such as SARS-CoV-2, can spread to the brain from the respiratory tract $(5,12,13)$, the occurrence of gastrointestinal symptoms (14) suggests that the gastrointestinal system is a possible route of invasion and transmission to the enteric nervous system (ENS) (see Figure 1). While the effects of COVID-2019 on olfactory and gustatory perception may be 


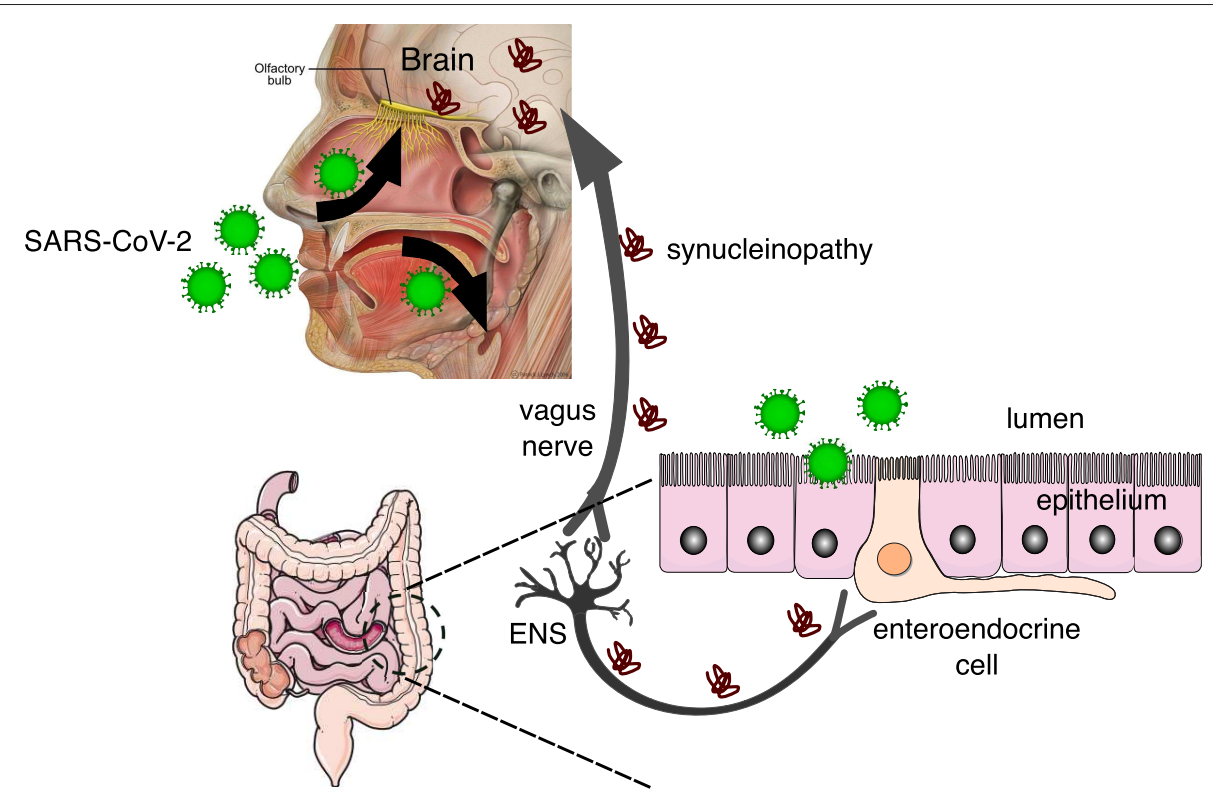

FIGURE 1 | SARS-CoV-2 invades the body through the nasal and oral cavities and may be transmitted to the brain via the olfactory bulb and the enteric nervous system (ENS). In the brain, the virus can cause neuroinflammation by microglial activation and also synucleinopathy that can be transmitted prion-like to other brain regions via the vagus nerve [adapted from Fonseca et al. (15)], from Servier Medical Art, licensed under a Creative Common Attribution 3.0 Generic License (https:// www.smart.servier.com/), and Patrick J. Lynch, licensed under a Creative Common Attribution 2.5 License (https://commons.wikimedia.org/wiki/File:Head_olfactory_ nerve_-_olfactory_bulb_en.png).

transient, the possibility that viruses and other contaminant agents can be the initiating etiology of neurodegenerative diseases such as Parkinson's disease (PD) has been raised before (16).

Parkinson's disease (PD) is a common neurodegenerative disorder associated with the progressive loss of dopaminergic neurons located in the midbrain nucleus substantia nigra pars compacta (SNpc) due to the accumulation of $\alpha$ synuclein ( $\alpha$-syn) aggregates. The Braak hypothesis (9) for the etiology of sporadic Parkinson's disease (PD) proposes that a neurotropic virus invading neural tissue through the nasal cavity and the gastrointestinal tract causes $\alpha$-syn to turn into a promiscuous binder and be transmitted, prion-like, to key areas such as the SNpc (15). Interestingly, the prodromal or preclinical phase of $\mathrm{PD}$ is also characterized by olfactory and gastrointestinal symptoms (17).

The cellular receptor for SARS-CoV-2 is the angiotensinconverting enzyme 2 (ACE2), which has a role in the metabolism of angiotensin peptides involved in the control of vasoconstriction and blood pressure (18). ACE2 is found in several tissues associated with cardiovascular function, but also in the brain, including brainstem nuclei involved with cardio-respiratory regulation $(19,20)$. Thus, respiratory problems in COVID-19 patients could also derive from the direct action of SARS-CoV-2 in respiratory control nuclei in the Brain (21). Through its binding to ACE2 receptors,
SARS-CoV-2 may spread transneuronally to distant brain targets, similar to other neurotropic viruses (22), as predicted by the Braak hypothesis.

Thus, recovery may be an ambiguous term regarding COVID19. Though recovery from the acute phase of the infections is certainly a relief in public health terms, helping to stop the spreading of the infection, one must consider the long-term neurological effects of the disease. This discussion has been conspicuously lacking in pertinent forums and needs to be adequately addressed as an important concern by public health officials. Many authorities are focusing only on the risks posed to the elderly and immunocompromised subjects, downplaying the threats to younger populations. Though the neurological risks described in the present work are particularly important to the elderly, due to age-related degenerative processes in the immunologic system and the brain, the population needs to be alerted to the chronic neurological risks during the pandemic and maintain social distancing for as long as it is necessary.

\section{AUTHOR CONTRIBUTIONS}

AP conceived and wrote the manuscript.

\section{FUNDING}

Financial support from Federal University of Pará (UFPA). 


\section{REFERENCES}

1. Zhou P, Yang X-L, Wang X-G, Hu B, Zhang L, Zhang W, et al. A pneumonia outbreak associated with a new coronavirus of probable bat origin. Nature. (2020) 579:270-3. doi: 10.1038/s41586-020-2012-7

2. Drosten C, Günther S, Preiser W, van der Werf S, Brodt H-R, Becker S, et al. Identification of a novel coronavirus in patients with severe acute respiratory syndrome. N Engl J Med. (2003) 348:1967-76. doi: 10.1056/NEJMoa 030747

3. Zaki AM, van Boheemen S, Bestebroer TM, Osterhaus ADME, Fouchier RAM. Isolation of a novel coronavirus from a man with pneumonia in Saudi Arabia. N Engl J Med. (2012) 367:1814-20. doi: 10.1056/NEJMoa1211721

4. Zhang $\mathrm{T}, \mathrm{Wu} \mathrm{Q}$, Zhang $\mathrm{Z}$. Probable pangolin origin of SARS-CoV2 associated with the COVID-19 outbreak. Curr Biol. (2020) 30:134651. doi: 10.1016/j.cub.2020.03.022

5. Desforges M, Le Coupanec A, Dubeau P, Bourgouin A, Lajouie L, Dubé M, et al. Human coronaviruses and other respiratory viruses: underestimated opportunistic pathogens of the central nervous system? Viruses. (2019) 12:14. doi: 10.3390/v12010014

6. Ludlow M, Kortekaas J, Herden C, Hoffmann B, Tappe D, Trebst C, et al. Neurotropic virus infections as the cause of immediate and delayed neuropathology. Acta Neuropathol. (2016) 131:159-84. doi: 10.1007/s00401-015-1511-3

7. Savarin C, Bergmann CC. Viral-induced suppression of self-reactive T cells: lessons from neurotropic coronavirus-induced demyelination. $J$ Neuroimmunol. (2017) 308:12-6. doi: 10.1016/j.jneuroim.2017.01.003

8. Beraki S, Aronsson F, Karlsson H, Ögren SO, Kristensson K. Influenza A virus infection causes alterations in expression of synaptic regulatory genes combined with changes in cognitive and emotional behaviors in mice. $\mathrm{Mol}$ Psychiatry. (2005) 10:299-308. doi: 10.1038/sj.mp.4001545

9. Braak H, Rüb U, Gai WP, Del Tredici K. Idiopathic Parkinson's disease: possible routes by which vulnerable neuronal types may be subject to neuroinvasion by an unknown pathogen. J Neural Trans. (2003) 110:51736. doi: 10.1007/s00702-002-0808-2

10. Wang D, Hu B, Hu C, Zhu F, Liu X, Zhang J, et al. Clinical characteristics of 138 hospitalized patients with 2019 novel coronavirus-infected pneumonia in Wuhan, China. JAMA. (2020) 323:1061-9. doi: 10.1001/jama.2020.1585

11. Yeager A. Lost Smell and Taste Hint COVID-19 Can Target the Nervous System. The Scientist Magazine (2020, March 24). Available online at: https:// www.the-scientist.com/news-opinion/lost-smell-and-taste-hint-covid-19can-target-the-nervous-system-67312 (accessed April 04, 2020).

12. Bohmwald K, Gálvez NMS, Ríos M, Kalergis AM. Neurologic alterations due to respiratory virus infections. Front Cell Neurosci. (2018) 12:386. doi: $10.3389 /$ fncel.2018.00386
13. Ding Y, He L, Zhang Q, Huang Z, Che X, Hou J, et al. Organ distribution of severe acute respiratory syndrome (SARS) associated coronavirus (SARS$\mathrm{CoV}$ ) in SARS patients: implications for pathogenesis and virus transmission pathways. J Pathol. (2004) 203:622-30. doi: 10.1002/path.1560

14. Gu J, Han B, Wang J. COVID-19: Gastrointestinal manifestations and potential fecal-oral transmission. Gastroenterology. (2020). doi: 10.1053/j.gastro.2020.02.054. [Epub ahead of print].

15. Fonseca S, de Oliveira HL, Yamada ES, Neves BC, Pereira A. The gut and Parkinson's disease-a bidirectional pathway. Front Neurol. (2020) 10:574. doi: 10.3389/fneur.2019.00574

16. Jang H, Boltz DA, Webster RG, Smeyne RJ. Viral parkinsonism. Biochim Biophys Acta. (2009) 1792:714-21. doi: 10.1016/j.bbadis.2008.08.001

17. Mahlknecht P, Seppi K, Poewe W. The concept of prodromal Parkinson's disease. J Parkinsons Dis. (2015) 5:681-97. doi: 10.3233/JPD-150685

18. Yan R, Zhang Y, Li Y, Xia L, Yingying G, Zhou Q. Structural basis for the recognition of the SARS-CoV-2 by full-length human ACE2. Science. (2020) 367:1444-8. doi: 10.1126/science.abb2762

19. Baig AM, Khaleeq A, Ali U, Syeda $H$. Evidence of the COVID-19 virus targeting the CNS: tissue distribution, hostvirus interaction, and proposed neurotropic mechanisms. ACS Chem Neurosci. (2020) 11:7. doi: 10.1021/acschemneuro.0 c00122

20. Doobay MF, Talman LS, Obr TD, Tian X, Davisson RL, Lazartigues E. Differential expression of neuronal ACE2 in transgenic mice with overexpression of the brain renin-angiotensin system. Am J Physiol Regul Integr Compar Physiol. (2007) 292:R373-81. doi: 10.1152/ajpregu.00292. 2006

21. Li YC, Bai WZ, Hashikawa T. The neuroinvasive potential of SARS-CoV2 may play a role in the respiratory failure of COVID-19 patients. J Med Virol. (2020). doi: 10.1002/jmv.25728. [Epub ahead of print].

22. McGavern DB, Kang SS. Illuminating viral infections in the nervous system. Nat Rev Immunol. (2011) 11:318-29. doi: 10.1038/ nri2971

Conflict of Interest: The author declares that the research was conducted in the absence of any commercial or financial relationships that could be construed as a potential conflict of interest.

Copyright (C) 2020 Pereira. This is an open-access article distributed under the terms of the Creative Commons Attribution License (CC BY). The use, distribution or reproduction in other forums is permitted, provided the original author(s) and the copyright owner(s) are credited and that the original publication in this journal is cited, in accordance with accepted academic practice. No use, distribution or reproduction is permitted which does not comply with these terms. 